$$
4
$$




\title{
PACHYCARE FLAVO-GRISEA.
}

\author{
Yellow-and-grey Thickhead.
}

\author{
Pachycephala flavo-grisea, Meyer, Sitz. Akad. Wien, lxix. p. 495 (1874).-Salvad. Ann. Mus. Civ. Genova, vii.
} p. 775 (1875).

In describing this bird as a Pachycephala Dr. Meyer seems to have had an idea that the species was by no means a typical one; and I need hardly do more than draw the attention of my readers to the bird figured in the opposite Plate to illustrate the very aberrant style of plumage exhibited by it as compared with the usual black and yellow or green dress of an ordinary Pachycephala. In point of fact, not only the plumage, but the form of the bird differs so strikingly that I feel compelled to institute a new generic title for its reception.

In the olden days, when the quinary system had sway, we should doubtless have been told that the present species represented the Sittidæ, or Nuthatches, among the Shrikes, if, indeed, the Pachycephaline birds are to be accounted as belonging to the great group of the Laniidæ. Their position is not well ascertained; and by some ornithologists they are considered to belong to the Ampelidæ, while Mr. D. G. Elliot raised them at one time to the rank of a family (Pachycephalidæ). Although the quinary theory is exploded, and its most potent advocates have passed away, one cannot be surprised at the hold that it once possessed on the minds of many earnest zoologists, as it brought forward characters and affinities which would perhaps have been otherwise neglected; only its advocates were inclined to push their ideas to too great an extreme. The resemblance in the present instance, however, is very striking, not only in the grey Nuthatch-like colour of the back, but even in the two long black stripes (so characteristic of the Sittæ) which run down each side of the neck.

Dr. Meyer obtained his type specimen in the Arfak Mountains, in March 1873; and more recently Count Salvadori has received two specimens from the same locality, sent by Dr. Bruijn. I am pleased to see that this excellent ornithologist is inclined to consider its generic separation expedient.

I am once more indebted to Dr. Meyer's kindness for the opportunity of figuring this interesting addition to the Papuan avifauna; and the following description is drawn up from the typical specimen.

Face, ear-coverts, throat, and undersurface bright yellow; crown of the bead and all the upper surface grey; a black mark intervening between the yellow face, ear-coverts, and the grey of the upper surface of the body. The three secondary wing-feathers next the body black, with a distinct square spot of white at their tips ; underparts of the wing white ; tail grey above, terminating in dusky black.

This is by no means a typical Pachycephala, and must receive an appellation as a new genus (PACHycARE), in which the following characters must be noted:-Plumage lax. Bill stout, with a distinct notch and overhanging tip on the upper mandible; vibrissæ absent. Wing rounded and feeble; first primary short, the fourth the longest. Tail short and rounded. Tarsi moderately long, exceeding the length of the bill, rather slight, as are the toes.

Total length 5 inches, bill $\frac{5}{8}$, wing $3 \frac{1}{4}$, tail $2 \frac{1}{8}$, tarsi $\frac{3}{4}$.

The figures in the Plate are of the natural size. 


\section{$2 \mathrm{BHL}$ Biodiversity Heritage Library}

Gould, John and Sharpe, Richard Bowdler. 1876. "Pachycare flavo-grisea, Yellow-and-Grey Thickhead [PI. 15]." The birds of New Guinea and the adjacent Papuan islands : including many new species recently discovered in Australia 3(III), -. https://doi.org/10.5962/p.322728.

View This Item Online: https://www.biodiversitylibrary.org/item/229963

DOI: https://doi.org/10.5962/p.322728

Permalink: https://www.biodiversitylibrary.org/partpdf/322728

\section{Holding Institution}

Smithsonian Libraries

\section{Sponsored by}

Biodiversity Heritage Library

\section{Copyright \& Reuse}

Copyright Status: Public domain. The BHL considers that this work is no longer under copyright protection.

This document was created from content at the Biodiversity Heritage Library, the world's largest open access digital library for biodiversity literature and archives. Visit BHL at https://www.biodiversitylibrary.org. 